\title{
Feeding dairy cows with soybean by-products: effects on metabolic profile
}

\author{
Alimentação de vacas leiteiras com subprodutos de soja: efeitos sobre o perfil metabólico
}

\author{
Marilia Alves $^{1}$ Félix González $^{*}$ Nelcy Carvalho $^{3}$ Paulo Mühlbach $^{4}$ \\ Verônica Lima $^{5}$ Tiago Reis Conceição $^{6}$ Vera Wald $^{7}$
}

\section{ABSTRACT}

Soybean by-products are currently used in Rio Grande do Sul, Brazil, as a source of protein in dairy cows. However, the high protein breakdown of this feed source in the rumen causes loss of the intrinsic quality of the protein and increases plasma urea with deleterious consequences to animal metabolism. Thermal treatment of soybean can overcome this limitation. The aim of this study was to evaluate the metabolism of dairy cows fed with thermally treated soybean and raw soybean, through the analyses of the metabolic profile of plasma and milk. Twelve Holstein cows in mid-lactation period were studied using four treatments: commercial concentrated of protein, soybean meal, raw soybean and roasted soybean. Protein and urea levels in milk were measured in morning and afternoon samples. Data were arranged in a Latin square design (4 treatments and 3 animals in each square). There were no significant differences in glucose, beta-hydroxybutyrate, calcium, phosphorus and magnesium concentrations among treatments. Cows consuming raw and thermally treated soybean had higher levels of plasma cholesterol. Cows consuming roasted soybean had lower level of plasma and milk urea in the morning. Afternoon milk samples had higher levels of urea than morning samples. It is suggested that thermally treated soybean was effective in diminishing the breakdown of protein in the rumen. It is better to employ morning milk samples to evaluate metabolic profile than afternoon samples.

Key words: metabolic profile, roasted soybean, dairy cows, milk, protein, urea.

\section{RESUMO}

Os subprodutos de soja vêm sendo utilizados como fonte protéica na alimentação de vacas leiteiras no Rio
Grande do Sul. Entretanto, a elevada degradabilidade ruminal desta fonte causa perda da qualidade intrínseca da proteína e leva a aumento da uréia plasmática, com conseqüências deletérias no metabolismo animal. $O$ tratamento térmico do grão de soja pode superar essa limitação. Este trabalho teve como objetivo avaliar o metabolismo de vacas leiteiras alimentadas com grão de soja cru e tratado termicamente, mediante o perfil metabólico no plasma e no leite. Foram utilizadas doze vacas da raça Holandesa no terço médio da lactação, nas quais foram aplicados quatro tratamentos: concentrado protéico comercial, farelo de soja, grão de soja cru e grão de soja tostado. No leite, foram dosados os teores de proteína e uréia. Não foram detectadas diferenças significativas entre os tratamentos na concentração de glicose, beta-hidroxibutirato, cálcio, fósforo e magnésio. Houve maiores níveis de colesterol plasmático nos animais consumindo grão de soja cru e tratado com calor. As vacas consumindo soja tostada tiveram menor teor de uréia no plasma e no leite da ordenha da manhã, sugerindo que o tratamento com calor no grão de soja foi efetivo para diminuir a degradação protéica no rúmen. Recomenda-se usar amostras de leite coletadas pela manhã para avaliar o perfil metabólico.

Palavras-chave: perfil metabólico, vacas leiteiras, leite, proteína, soja tostada, uréia.

\section{INTRODUCTION}

Raw soybean is currently used as an alternative source of protein in ruminant feeding. Nevertheless, as soybean proteins have a high degradability rate in rumen, it could result in excessive loss of nitrogen and in hepatic overload of ammonia,

\footnotetext{
${ }^{1}$ Veterinarian, MSc.

${ }^{3}$ Veterianrian, PhD, Professor, Center of Agricultural Sciences, Universidade Federal de Santa Maria.

${ }^{4}$ Agronomist, PhD, Professor, Department of Animal Science, UFRGS.

${ }^{5}$ Laboratory technician, LACVET/UFRGS.

${ }^{6}$ Veterinarian.

${ }^{7}$ Veterinarian, PhD, Professor at the Faculty of Veterinary, UFRGS.

*Corresponding author: PO Box 15094, Porto Alegre, RS, Brazil. E-mail: felixgon@orion.ufrgs.br
}

${ }^{2}$ Veterinarian, PhD, Professor, Faculty of Veterinary, Universidade Federal do Rio Grande do Sul (UFRGS), Porto Alegre, RS, Brazil. 
causing deleterious effects on reproductive performance of dairy cows. In order to minimize possible damages caused by excessive degradability of protein, has been used lately the treatment of soybean with heat (SHAVER, 1999), as well as with chemical products (NRC, 2001). Heat treatment may be of better economic results. Heat treatment provokes the formation of binding bridges between peptides chains and carbohydrates ("Maillard reaction"), diminishing protein degradability in the rumen (SHAVER, 1999). Besides the protective effect on protein degradation, heat is also used to minimize anti-nutritional factors present in soybean (REDDY \& MORRILL, 1993). HSU \& SATTER (1995) showed that thermal treatment ideal for soybean would be $146^{\circ} \mathrm{C}$, followed by steeping of 30 minutes. Steeping refers to the procedure after toasting, when soybean is placed in a thermal recipient for a defined time, normally thirty minutes, so that heat penetrates more deeply in the grains.

Most of metabolic disorders may be detected by the use of blood biochemical profile (PAYNE \& PAYNE, 1987). Increased protein degradability in the rumen, leads to an excess of ammonia (NH ) that could affect energy balance (GARCIA-BO\}ALIL et al., 1998). Energy/protein balance in the ruminants feed is essential for a good utilization of urea. Seasonal or even daily variations in the diet have influence on blood urea levels and its use by the animal (WITTWER, 1993). High levels of degradable protein in the feed may raise blood urea and low reproductive performance, provoked by the deleterious effect of urea on uterus (MOORE \& VARGA, 1996). Milk urea levels (MUN) are reliable to reflect blood urea levels (BUN) and help to diagnose protein/energy balance of the diet (WESTWOOD et al., 1998). Monitoring levels of milk urea helps to determine nutritional status in dairy cows and is largely recommended by many authors (EICHER et al., 1999). Biochemical tests on milk can also be used in the study of metabolic status of the animal to diagnose energy deficiencies, as in clinical and non-clinical ketosis in early lactation (HAMANN \& KRÖMKER, 1997).

The present work had the aim of evaluating the nutritional status, using metabolic profile test, of dairy cows feeding raw and thermally treated soybean, and to infer the by-pass effect of thermic treated soybean by examining milk protein and urea concentrations.

\section{MATERIAL AND METHODS}

This work was carried out in a dairy farm located at the northwest region of the State of Rio
Grande do Sul (southern Brazil). Twelve cows, chosen among clinically healthy animals with a mean of 147 days in lactation were used in the research. The animals were distributed in four treatments of three cows each. Mean milk yield of the cows used in the experiment was $26.3 \mathrm{~kg} / \mathrm{cow} / \mathrm{day}$. The number of lactations was 25 and body weight was between 525 and $694 \mathrm{~kg}$.

The treatments represent diets with different protein sources in feed. All diets were isonitrogen ( $17.4 \%$ crude protein), isocaloric $(1.5 \mathrm{MCal} / \mathrm{kg})$ and were balanced to satisfy nutrient requirements (Spartan Dairy Ration Evaluator/Balancer, CP-012, version 2.01). The diets had the following composition in relation to protein fraction: protein concentrate (treatment 1), soybean meal (treatment 2), raw soybean (treatment 3 ) and thermally treated soybean (treatment 4). All diets contained $21 \mathrm{~kg}$ of dry matter.

Thermic treatment was made in an experimental oven reaching $146^{\circ} \mathrm{C}$ in the grain, with a steeping of 30 minutes (HSU \& SATTER, 1995). All animals were kept in free stall and fed three times daily. The diets were offered totally mixed and with water $a d$ libitum. Each group of three animals received one of the treatments during 14 days, and after this period, shifted to the next treatment and so on until all groups suffered all treatments (Latin squared design).

Blood samples were collected on the last day of each period (14th day). Sampling period was between November/2000 and January/2001, corresponding to summer season in southern Brazil. A previous period of three weeks was allowed for adaptation of the animals. Blood samples $(10 \mathrm{~mL})$ were obtained from the coccigeal vein during the second feed of the day (13:30h to $15: 00 \mathrm{~h})$, in vacutainer tubes with sodium heparin as anticoagulant. Then, were centrifuged ( $1500 \mathrm{~g}$ for 15 minutes) and plasma kept in eppendorf tubes under refrigeration (ice box) during its transportation to the laboratory, where they were stored at $-20^{\circ} \mathrm{C}$ until its chemical analysis. Milk samples were also collected on the last day of each treatment period for determination of urea and total protein. Two milk samples were collected each time, in the morning and in the afternoon, in tubes with sodium azide and sent to the laboratory.

The following metabolites were determined in plasma by colorimetric assays: glucose (glucose oxidase method) ${ }^{1}$, beta-hydroxibutirate (UV enzymatic method) ${ }^{2}$, cholesterol (cholesterol esterase/oxidase method) ${ }^{3}$, albumin (bromocresol green method) ${ }^{4}$, total protein (biuret method) ${ }^{5}$, urea (urease method) ${ }^{6}$, aspartate aminotransferase (UV enzymatic method) ${ }^{7}$, calcium (purple ftalein method) ${ }^{8}$, phosphorus (ammonium molibdate method) ${ }^{9}$ and magnesium 
(magon-sulfonade method) ${ }^{10}$. Urea in milk was performed by Berthelot modified method, as described by WITTWER et al. (1993). Milk protein was performed by near infrared spectroscopy (NIRS) in Bentley 2000 equipment.

Data were organized in Latin square design, with four treatments and three animals in each Latin square. Statistical analysis was performed using Mixed Models (SAS, 1996). For comparison among means LSMEANS procedure was used, with a significance level of $5 \%$.

\section{RESULTSAND DISCUSSION}

The study of the animal protein status includes the blood determination of albumin, globulins and urea (PAYNE \& PAYNE, 1987). Urea represents the immediate intake of crude protein, while albumin reflects long-term protein status. Plasma albumin levels could be altered by effect of liver function, protein and energy intake, age and protein losses during certain diseases, as in parasitism. Table 1 shows mean values of albumin, globulins and urea in the four treatments. Albumin levels were similar to those reported by WITTWER (2000) in Chile but higher than values found by GONZÁLEZ et al. (1999) in southern Brazil. The group fed with concentrate had higher albumin concentration $(38.9 \mathrm{~g} / \mathrm{L})$, followed by animals fed with roasted soybean $(38.5 \mathrm{~g} / \mathrm{L})$. There were no significant differences among treatments $(\mathrm{P}>0.05)$. Globulin levels were similar to those reported by GONZÁLEZ et al. (1999) without significant differences among groups.

Urea plasma levels were higher than values reported by WITTWER (2000) but similar to those reported by GONZALEZ et al. (1999). There were no significant differences among groups $(\mathrm{P}>0.05)$ although the urea concentration in cows feeding roasted soybean was lower than all other groups, which

Table 1 - Mean values and standard deviation (SD) of plasmatic concentration of albumin, globulins and urea in cows feeding different protein sources

\begin{tabular}{lcccccc}
\hline \multirow{2}{*}{ Treatment } & \multicolumn{2}{c}{$\begin{array}{c}\text { Albumin } \\
(\mathbf{g} / \mathbf{L})\end{array}$} & \multicolumn{2}{c}{$\begin{array}{c}\text { Globulins } \\
(\mathbf{g} / \mathbf{L})\end{array}$} & \multicolumn{2}{c}{$\begin{array}{c}\text { Urea } \\
(\mathbf{m m o l} / \mathbf{L})\end{array}$} \\
\cline { 2 - 7 } & Mean & S.D. & Mean & S.D. & Mean & S.D. \\
\hline [1] Concentrate & 38.9 & 3.01 & 55.3 & 13.28 & 7.28 & 0.93 \\
[2] Soybean meal & 38.0 & 3.57 & 56.1 & 14.42 & 7.36 & 1.11 \\
[3] Raw soybean & 37.9 & 4.03 & 52.7 & 10.77 & 7.49 & 0.48 \\
[4] Roasted soybean & 38.5 & 4.25 & 55.3 & 10.25 & 6.83 & 0.89 \\
\hline
\end{tabular}

( $\mathrm{P}>0.05$, no significant difference) could be related with diminished protein degradability in rumen probably caused by thermic treatment of soybean.

Energy metabolism may be studied by determining plasma glucose, beta-hydroxybutyrate (BHB) and cholesterol (PAYNE \& PAYNE, 1987). Glucose values were slightly higher than those reported for cows in early lactation (GONZÁLEZ et al., 1999). There were no significant differences in glucose and BHB levels among treatments (Table 2). Cholesterol means were higher in cows feeding raw soybean, maybe as a consequence of oil presence in that feed source (NRC, 2001). Cholesterol values of the other groups were similar to studies in southern Latin America (WITTWER, 2000; GONZÁLEZ et al., 1999).

Liver function can be monitored in cows with plasma levels of the enzyme aspartate transaminase (AST), albumin, glucose and cholesterol (PAYNE \& PAYNE, 1987). In the present work all those parameters fell in a reference range that indicates an adequate function of the liver. Also, there were no significant differences among treatments $(p>0.05)$.

Calcium, phosphorus and magnesium were studied. Calcium plasma concentration is under rigorous endocrine control, but it would be affected by diet (CORBELLINI, 1998). In this work, calcium levels were in accordance with reference values (Table 3). Cows fed with meal and raw soybean had lower calcium concentrations without significant differences among treatments $(\mathrm{P}>0.05)$.

One of the main interest of mineral metabolic profile is inorganic phosphorus $(\mathrm{P})$ which has a less efficient control than calcium in plasma but its concentration may vary with lactation, pregnancy and nutritional deficiencies (GONZÁLEZ, 2000). In this work, mean levels of $\mathrm{P}$ above reference values were observed (WITTWER, 2000). There were no significant differences among groups of cows. Magnesium values were similar to those referenced by GONZÁLEZ et al. (1999) and WITTWER (2000) without significant difference among groups $(\mathrm{P}>0.05)$.

Factors affecting protein contents in milk include the by-pass protein, quality of ration and the rate of protein synthesis by rumen bacteria, which depends on energy/protein balance of the diet. In the present work, levels of milk protein were similar in all treatments $(\mathrm{p}>0.05)$ and fell in intervals recommended by INTA (1996), which are between 2.6 and $4.0 \%$ (Table 4 ).

Milk urea levels obtained in the morning milking were lower than those obtained in the afternoon milking (Table 4). The latter data were higher 
Table 2 - Mean values and standard deviation (SD) of plasmatic concentration of glucose, beta-hydroxybutyrate (BHB), cholesterol and aspartate transaminase (AST) in cows feeding different protein sources

\begin{tabular}{|c|c|c|c|c|c|c|c|c|}
\hline \multirow{2}{*}{ Treatment } & \multicolumn{2}{|c|}{ Glucose (mmol/l) } & \multicolumn{2}{|c|}{$\mathrm{BHB}(\mathrm{mmol} / \mathrm{l})$} & \multicolumn{2}{|c|}{ Cholesterol (mmol/l) } & \multicolumn{2}{|c|}{$\mathrm{AST}(\mathrm{U} / \mathrm{l})$} \\
\hline & Mean & S.D. & Mean & S.D. & Mean & S.D. & Mean & S.D. \\
\hline [1] Concentrate & 3.93 & 1.04 & 0.36 & 0.11 & $5.53^{\mathrm{b}}$ & 1.60 & 67.11 & 11.39 \\
\hline [2] Soybean meal & 3.91 & 1.12 & 0.36 & 0.09 & $5.0^{\mathrm{c}}$ & 0.67 & 70.31 & 13.39 \\
\hline [3] Raw soybean & 3.67 & 0.67 & 0.39 & 0.10 & $6.54^{\mathrm{a}}$ & 1.13 & 73.79 & 10.98 \\
\hline [4] Roasted soybean & 3.66 & 0.32 & 0.35 & 0.06 & $6.31^{\mathrm{b}}$ & 0.88 & 75.44 & 15.73 \\
\hline
\end{tabular}

${ }^{\mathrm{a}, \mathrm{b}, \mathrm{c}}$ Values with different letters have significant difference among treatments $(\mathrm{P}<0.05)$.

Table 3 - Mean values and standard deviation (SD) of plasmatic concentration of calcium, phosphorus and magnesium in cows feeding different protein sources

\begin{tabular}{lccccc}
\hline & \multicolumn{2}{c}{ Calcium (mmol/l) } & \multicolumn{2}{c}{ Phosphorus (mmol/l) } & \multicolumn{2}{c}{ Magnesium(mmol/l) } \\
Treatment & Mean & S.D. & Mean & S.D. & Mean \\
S1] Concentrate & 2.22 & 0.63 & 2.64 & 0.82 & 0.14 \\
[2] Soybean meal & 1.94 & 0.25 & 2.45 & 0.61 & 1.03 \\
[3] Raw soybean & 2.06 & 0.22 & 2.70 & 0.56 & 1.07 \\
[4] Roasted soybean & 2.13 & 0.11 & 2.80 & 0.49 & 1.13 \\
\hline
\end{tabular}

(P>0.05: no significant difference)

Table 4 - Mean values and standard deviation (SD) of milk protein percentage and urea concentration (mmol/L) from morning and afternoon milking in cows feeding different protein sources

\begin{tabular}{lcccc}
\hline \multirow{2}{*}{ Protein percentage } & \multicolumn{2}{c}{ Treatment } \\
\cline { 2 - 5 } & Concentrate & Soybean meal & Raw soybean & Roasted soybean \\
\hline Morning & $3.14 \pm 0.28$ & $3.19 \pm 0.31$ & $3.10 \pm 0.24$ & $3.02 \pm 0.22$ \\
Afternoon & $3.12 \pm 0.25$ & $3.18 \pm 0.24$ & $3.11 \pm 0.20$ & $3.06 \pm 0.26$ \\
Total & $3.13 \pm 0.25$ & $3.19 \pm 0.26$ & $3.10 \pm 0.21$ & $3.04 \pm 0.22$ \\
Urea concentration & & & & \\
Morning & $5.71^{\mathrm{b}} \pm 1.37$ & $6.74^{\mathrm{a}} \pm 0.77$ & $6.92^{\mathrm{a}} \pm 1.08$ & \\
Afternoon & $7.06 \pm 0.98$ & $7.40 \pm 0.93$ & $7.39 \pm 0.88$ & $7.75 \pm 0.56$ \\
Total & $6.38^{\mathrm{b}} \pm 1.15$ & $7.07^{\mathrm{a}} \pm 0.50$ & $7.15^{\mathrm{a}} \pm 0.83$ & $6.92^{\mathrm{b}} \pm 0.56$ \\
\hline
\end{tabular}

${ }^{\mathrm{a}, \mathrm{b}, \mathrm{c}}$ Values with different letters have significant differences among treatments $(\mathrm{P}<0.05)$.

than those reported by Witter (2000). According to MIETTINEN \& JUVONE (1990) diurnal variations of milk urea are normal and generally have higher values than morning samples. There were significant differences in milk urea levels among treatments $(\mathrm{P}<0.05)$ in morning milking which might be attributed to different degradability of protein sources in the diets. Protein concentrate (treatment 1) and roasted soybean (treatment 4) had less milk urea values than soybean meal (treatment 2) and raw soybean (treatment
3). This finding suggests that roasted soybean protein had less protein degradability in rumen than raw and meal soybean. Afternoon milking did not show differences among treatments $(\mathrm{P}>0.05)$.

MOORE \& VARGA (1996) mentioned that ammonia peak in rumen occurs 1.5 to $2 \mathrm{~h}$ after feed intake, urea peak in plasma occurs 2 to $3 \mathrm{~h}$ after ammonia peak in rumen and urea peak in milk occurs 1.5 to $2 \mathrm{~h}$ after plasma urea peak. It means that milk urea peak occurs approximately $5 \mathrm{~h}$ after feeding. In this 
experiment, food was offered from 13:30h and afternoon milk sampling was done from between 17:30 and 18:00 that means, approximately at milk urea peak. According to these results, morning milk samples should have less interference of feeding than afternoon samples, which suggest that studies on milk components designed to evaluate feeding effects, should use morning samples.

\section{AKNOWLEDGEMENTS}

The authors are greatfull to FAPERGS (Fundação de Apoio à Pesquisa do Rio Grande do Sul) for research support.

\section{ACQUISITIONSOURCES}

${ }^{1}$ GOD-ANA (Labtest Diagnostics, Lagoa Santa, MG, Brazil): cat. n. 34E.

${ }^{2}$ Ranbut (Randox, Antrim, United Kingdom): cat. n. RB1007.

${ }^{3}$ Cholesterol-Liquiform (Labtest Diagnostics, Lagoa Santa, Brazil): cat. n. 76-2/100.

${ }^{4}$ Albumin (Labtest Diagnostics, Lagoa Santa, MG, Brazil): cat. n. 19.

${ }^{5}$ Total protein (Labtest Diagnostics, Lagoa Santa, MG, Brazil): cat. n. 18

${ }^{6}$ Urea CD (Labtest Diagnostics, Lagoa Santa, MG, Brazil): cat. n. 27.

${ }^{7}$ AST-Liquiform (Labtest Diagnostics, Lagoa Santa, MG, Brazil): cat. n. 75-4/30.

${ }^{8}$ Ca-Liquiform (Labtest Diagnostics, Lagoa Santa, MG, Brazil): cat. n. 90-2/60

${ }_{9}$ Phosphorus (Labtest Diagnostics, Lagoa Santa, MG, Brazil): cat. n. 42

${ }^{10}$ Magnesium (Labtest Diagnostics, Lagoa Santa, MG, Brazil): cat. n. 50 .

\section{REFERENCES}

CORBELLINI, C.N. Etipatogenia y control de hipocalcemia e hipomagnesemia em vacas lecheras. In: SEMINÁRIO INTERNACIONAL SOBRE DEFICIÊNCIAS MINERAIS EM RUMINANTES. Porto Alegre, RS. Anais... Porto Alegre : UFRGS, 1998. p.73-110.

EICHER, R.; BOUCHARD, E.; BISGRAS-PULIN, M. Factors affecting milk urea nitrogen and protein concentrations in Quebec dairy cows. Prev Vet Med v.39, p.53-63, 1999.

GARCIA-BOJALIL, C.M. et al. Protein degradability and calcium salts of long-chain fatty acids in the diets of lactating dairy cows: productive responses. J Dairy Sci, v.81, p.13741384, 1998.

GONZÁLEZ, F.H.D. Indicadores sangüíneos do metabolismo mineral em ruminantes. In: PERFIL METABÓLICO EM RUMINANTES: SEU USO EM NUTRIÇÃO E DOENÇAS
NUTRICIONAIS. Porto Alegre, RS. Anais... Porto Alegre : UFRGS, 2000. p.31-52.

GONZÁLEZ, F.D.H. et al. V alores de referência de bioquímica sangüínea e hemograma em vacas leiteiras no RGS. In: SALÃO DE EXTENSÃO DE UFRGS, 1., 1999, Porto Alegre, RS. Anais... Porto Alegre : UFRGS, 1999. p.237.

HAMANN, J.; KRÖMKER, V. Potential of specific milk composition variables for cow health management. Livestock Prod Sci v.48, p.201-208, 1997.

HSU, J.T.; SATTER, L.D. Procedures for measuring the quality of heat-treated soybeans. J Dairy Sci v.78, p.1353-1361, 1995.

INTA. Proteína en leche y su relación con el manejo nutricional. Rafaela : Estación Experimental Agropecuaria, 1996. 56p. (Informe Técnico).

MIETTINEN, P.V.A.; JUVONEN, R.O. Diurnal variations of serum and milk urea levels in dairy cows. Acta Agric Scand v.40, p.12-20, 1990.

MOORE, D.A.; VARGA, G. BUN and MUN: urea nitrogen testing in dairy cattle. Comp Cont Educ Pract Vet, v.18, p.712-720, 1996 .

NRC (NATIONAL RESEARCH COUNCIL) Nutrient requirements of dairy cattle. $7^{\text {th }}$ revised edition. Washington, D.C.: National Academy, 2001. 408p.

PAYNE, J.M.; PAYNE, S. The metabolic profile test. New York : Oxford University, 1987. 179p.

REDDY, P.V.; MORRILL, J.L. Effect of roasting temperatures on soybean utilization by young dairy calves. J Dairy Sci v.76, p.1387-1393, 1993.

SHAVER, R. Proteínas de soya para vacas en lactación. Alimentos Balanceados para Animales, jul/ago, p.14-17, 1999.

SAS, Institute Inc. SAS User's Guide. Version 6.12. Cary, NC, USA : SAS Institute, 1996. 1042p.

WESTWOOD, C.T.; LEAN, I.J.; KELLAWAY, R.C. Indications and implications for testing of milk urea in dairy cattle: a quantitative review. Part 1. Dietary protein sources and metabolism. New Zealand Vet J, v.46, p.87-96, 1998.

WITTWER, F. Marcadores bioquímicos no controle de problemas metabólicos nutricionais em gado de leite. In: PERFIL METABÓLICO EM RUMINANTES: SEU USO EM NUTRIÇÃO E DOENÇAS NUTRICIONAIS, 2000, Porto Alegre, RS. Anais... Porto Alegre : UFRGS, 2000. p.53-62.

WITTWER, F.; REYES, J.M.; OPTIZ, H. Determinación de urea en muestras de leche de rebaños bovinos para el diagnóstico de desbalance nutricional. Arch Med Vet, v.25, p.165-172, 1993. 